\title{
THE DISTRIBUTION OF WOODY LEGUMES IN NEOTROPICAL DRY FORESTS: THE PLEISTOCENE ARC THEORY 20 YEARS ON*
}

\author{
V. Y. Mognili, ${ }^{1,2}$ L. J. OAKLeY ${ }^{1}$ \& D. E. Prado ${ }^{1,2,3}$
}

The Pleistocene Arc Theory (PAT) suggests that present-day disjunct fragments of dry forests in central tropical South America give evidence of a previously more continuous distribution during the Pleistocene that has been disrupted by dry-cold vs. humid-warm climatic cycles. This Arc extends from NE Brazil to NE Argentina and eastern Paraguay, through the Chiquitanía to NW Argentina and SW Bolivia and into the dry inter-Andean valleys in Peru and Ecuador, with intrusions into the Great Chaco. Seasonally Dry Tropical Forests (SDTFs) are floristically and physiognomically dominated by woody legumes, mostly deciduous in the dry season. In the last two decades field collection and research on legume taxa has greatly increased, with a significant number of taxonomic revisions and molecular phylogenetic studies, together with some paleoclimatic modelling studies. The evidence accumulated in the last 23 years has confirmed the integrity of the Chaco and Caatingas phytogeographical provinces, with an impressive and increasing level of botanical endemism discovered. The PAT pattern has also been supported, specifically through the mapping of five selected woody Leguminosae species (Anadenanthera colubrina, Enterolobium contortisiliquum, Pterogyne nitens, Amburana cearensis and Piptadenia viridiflora). The pre-existing nuclei of South American SDTF (Caatingas, Misiones and Piedmont) are now increased to four with the postulation of the Chiquitanía Nucleus in south-eastern Bolivia and bordering Paraguay. Some new endemisms are compiled from recent literature and mapped for the Misiones and Chiquitanía nuclei. The need for more botanical collections and further taxonomic, phylogenetic and demographic studies of South American legumes is emphasised.

Keywords. Chiquitanía, dry forests, Leguminosae, phytogeography, Pleistocene Arc.

\section{INTRODUCTION}

The seasonally dry areas of the tropics, their ecosystems and vegetation types, have received scant attention from the natural sciences, especially when compared to that given to tropical rain forests (Janzen, 1988; Mooney et al., 1995). Only in recent times has this tendency been partially reversed (e.g. Pennington et al., 2006; Dirzo et al., 2011).

1 Cátedra de Botánica, Facultad de Ciencias Agrarias, UNR, Campo Experimental Villarino, C.C. N 14 , S2125ZAA Zavalla, Santa Fe, Argentina.

2 Consejo Nacional de Investigaciones Científicas y Técnicas (CONICET).

3 Author for correspondence. E-mail: dprado@unr.edu.ar

* Dedicated to the memory of the Brazilian geographer Aziz Nacib Ab'Sáber (1924-2012), whose papers on the geological past of South America fuelled the conception of the PAT hypothesis. 
In the Neotropics, Seasonally Dry Tropical Forests (SDTFs) are floristically and ecologically distinct vegetation types, clearly separated from rain forests (Pennington et al., 2000, 2009; Mayle, 2004) or the Chaco subtropical to temperate dry forests (Prado, 1993a, 1993b), and they must be considered separately in any biogeographical analyses. For much of the 20th century, the neotropical seasonally dry forests of central South America remained conceptually submerged within other neighbouring vegetation units of the continent, such as the Chaco and Yungas, or amongst the several units of the Amazonian Dominium (e.g. Cabrera, 1953, 1971; Rizzini, 1963; Hueck, 1978; Cabrera \& Willink, 1980; Hueck \& Siebert, 1981). This was a result of their spatial discontinuity.

Moreover, for nearly half a century two South American forest and woodland ecosystems were wrongly considered very similar; this confusion apparently stemmed from a misinterpretation of the seminal work by Smith \& Johnston (1945). These are the phytogeographical dominia or 'provinces' (sensu Takhtajan, 1986) of the Chaco and the Caatingas, both dominated by woody species of Mimosoideae (Leguminosae), separated by the extensive Cerrado vegetation of central Brazil (Fig. 1). Based on the high level of endemism in Chaco s.s. (Prado, 1993b), the even higher level of endemism of the Caatingas (Prado, 2003; Giulietti et al., 2006), and the negligible floristic links between the two ecosystems, this presumed similarity was demonstrated to be incorrect (Prado, 1991, 2000). Nevertheless, from an analysis of the non-endemic Caatingas woody species, a repeated and consistent disjunct pattern of distribution was established for the neotropical seasonally dry tropical forests.

After comprehensive mapping of several woody species of the South American SDTF (Prado, 1991) and numerical vegetation analysis, a strongly coincidental phytogeographical distribution pattern was revealed. This pattern goes across the continent in an arc shape (Fig. 2), extending from the Caatingas of north-eastern Brazil (the 'Caatingas Nucleus') to the sector formerly occupied by the Jesuit Missions of SE Brazil, eastern Paraguay and NE Argentina (the 'Misiones Nucleus'), then along the Bolivian Chiquitanía to the area of the sub-Andean foothills of SW Bolivia and NW Argentina (the 'Piedmont Nucleus'), and finally along the dry inter-Andean valleys of Bolivia, Peru and southern Ecuador (Prado \& Gibbs, 1993). This fragmentary and disjunct distribution of SDTF has been proposed as a new phytogeographical dominium, taking both varieties of Anadenanthera colubrina (Vell.) Brenan (Mimosoideae, Leguminosae) as its principal indicator tree species. This proposal was based not only on the number of endemic woody plant taxa (both at the species and genus level) but also on the greater similarity of these SDTF fragments to each other than to other surrounding vegetation units (Prado, 2000).

This new floristic and ecological interpretation of the South American SDTF led to the proposal of the so-called 'Pleistocene Arc Theory' (PAT) (Prado \& Gibbs, 1993). Whereas the alleged Chaco-Caatingas connections proved to be incorrect, the newly emerging distribution pattern across South America gave rise to speculations about the influence of past wet-dry climatic fluctuations on present-day disjunctions of seasonal forests in the continent, with an associated impact on biogeography and 


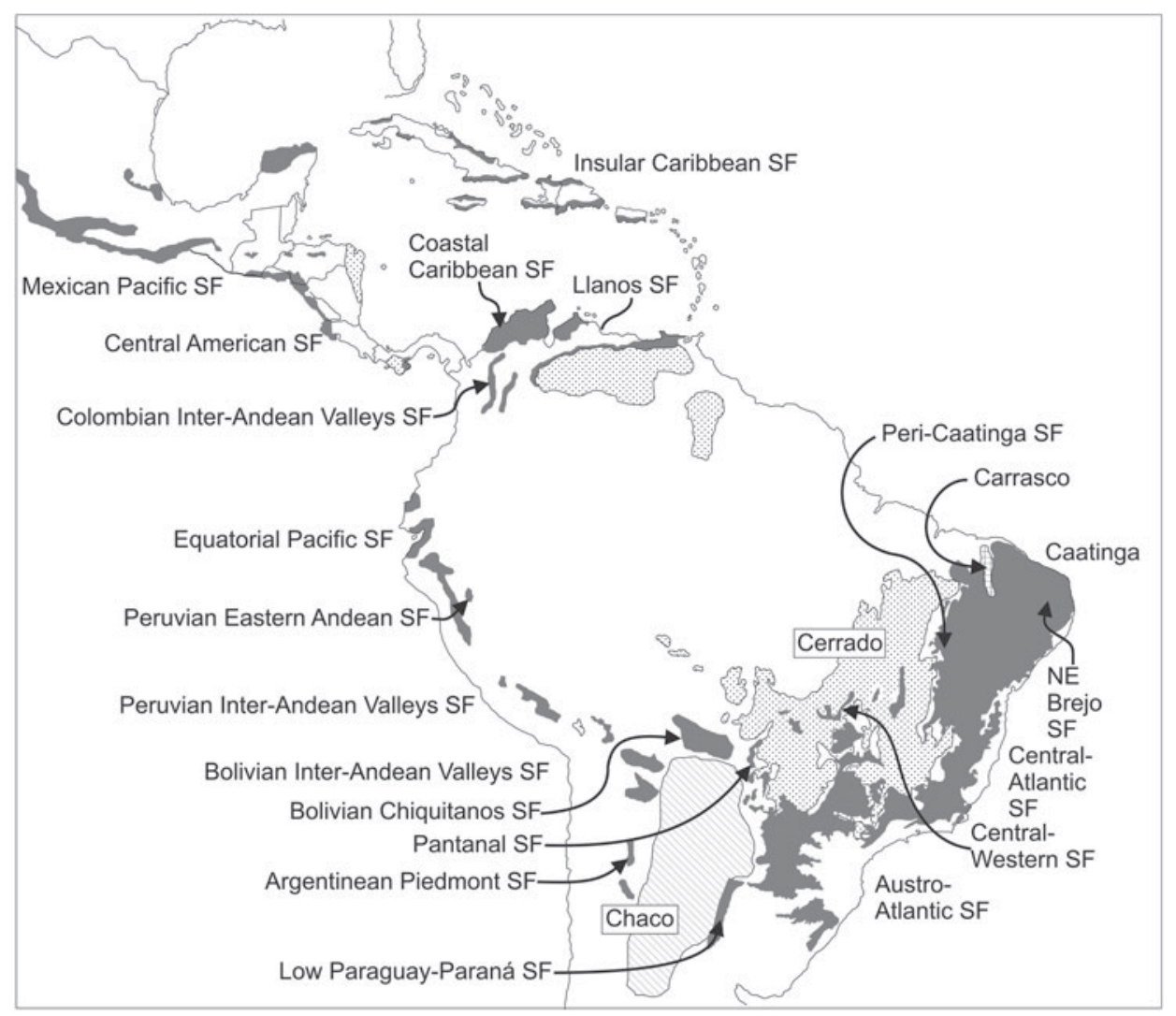

Fig. 1. Distribution of the Seasonally Dry Tropical Forests (SDTFs) in South America. All major forest nuclei are indicated. The Caatinga Nucleus, as here understood, also includes the North-East Brejo and Peri-Caatinga nuclei. The Chaco and savannas (Llanos and Cerrado) are also shown. Figure from Särkinen et al. (2011), modified from Linares-Palomino et al. (2011). SF: Seasonal Forests.

paleobiogeography (Pennington et al., 2000; Mayle, 2004). As a possible explanation for the PAT pattern, vicariance has been preferred, given that a single vicariance event is more parsimonious than several independent long-distance dispersals. Today, there is mounting evidence in favour of long-distance dispersal to explain the distribution of the succulent biome on an intercontinental scale (e.g. Davis et al., 2002; Lavin et al., 2004; Schrire et al., 2005a, 2005b, 2009) as well as that of certain neotropical forest distribution patterns (e.g. Pennington \& Dick, 2004; Dick \& Heuertz, 2008). Both the latter mainly refer to rain forest species, with the probable single exception of the wide-ranging Cordia alliodora (Ruiz \& Pav.) Oken (Rymer et al., 2013). Therefore, it is still possible that these disjunct fragmented patterns of distribution are vestiges of a more continuous SDTF formation that had a wider distribution during the drier glacial periods of the Pleistocene (Ab’Sáber, 1957, 1977, 1982, 2000). 


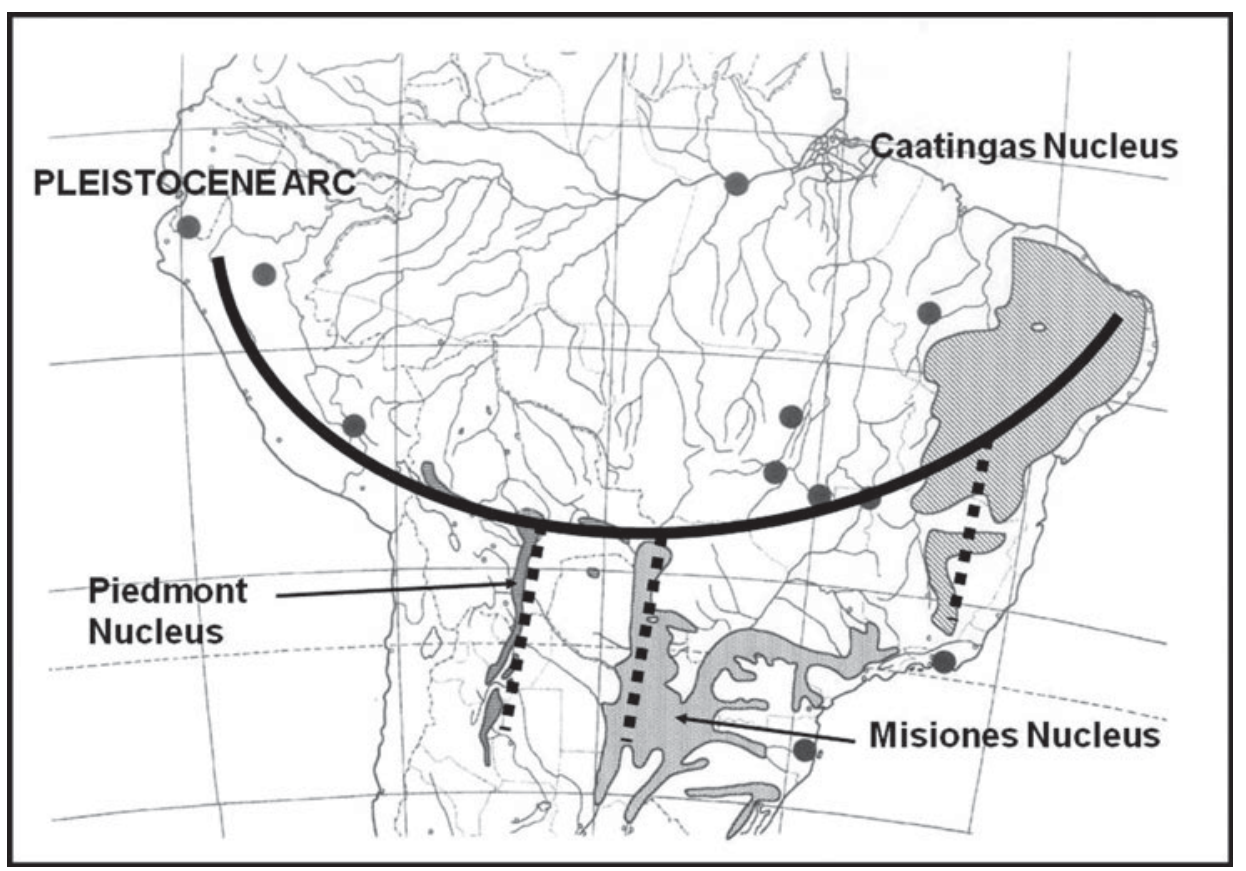

FIg. 2. The Pleistocene Arc of SDTF of central South America. All major dry forest nuclei are indicated. Modified from Prado (2000).

The present-day concept of SDTF in South America comprises woody vegetation types related to a strong seasonality, with a well-defined dry season of very variable length. In general terms, these forests are almost completely deciduous during the dry season (Fig. 3), thriving on fertile soils with slightly acid to neutral or somewhat alkaline $\mathrm{pH}$. Floristically they are dominated by Leguminosae (mainly Mimosoideae), frequently accompanied by Anacardiaceae and Bignoniaceae, usually with conspicuous flowers that open near the end of the dry season, later resulting in anemophilous propagules. The understorey comprises numerous species of Cactaceae and Bromeliaceae, and to a lesser degree broad-leaved herbs and Gramineae.

Since the PAT hypothesis is mainly based on comparison of floristic lists, taxonomic revisions and dot mapping of selected woody species, one valid criticism may be insufficient plant collections and incomplete or partial botanical studies, both of which could have led to incomplete or erroneous conclusions. This potential drawback was pointed out in a previous paper (Prado, 2000), which postulated that distribution patterns could have simply reflected well-collected areas or routes. In the past 23 years a plethora of new herbarium collections has been made and a sizeable number of monographic taxonomic studies has been carried out, particularly in Leguminosae. Most of the new legume collections and their accompanying information are now easily accessible online. In the present contribution an analysis is made of the distribution patterns of selected woody SDTF species, comparing their distribution based on all 


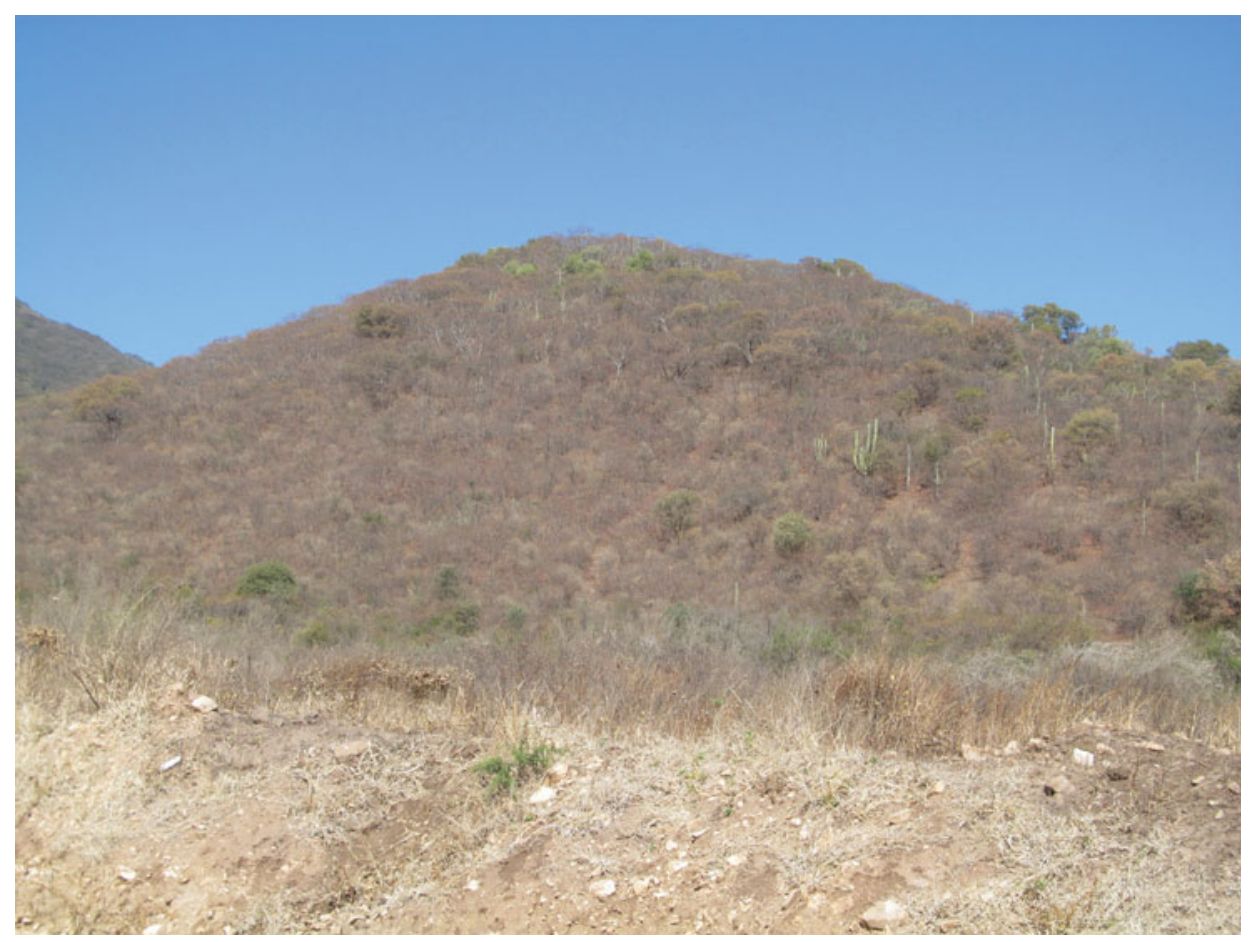

Fig. 3. Dry season in SDTF, near Salta, Argentina. Photo: O. G. Martínez.

currently available collections with their distribution presented at the time of the proposed PAT theory. Also, in a search for new evidence to support or refute the theory, more recent taxonomic studies have been reviewed. The questions we set out to answer are: (i) is the PAT still supported; and (ii) are there any additional legume endemics known from the Chaco and Caatingas?

\section{Material and Methods}

Most authors agree that a phytogeographic 'region' should contain a number of endemic genera and species, whereas 'provinces' (or 'dominia') that make up the subdivisions of a region should have a reduced number of monotypic or oligotypic genera but abundant specific endemism (Braun-Blanquet, 1919; Cain \& Castro, 1959; Takhtajan, 1986). Furthermore, Cain \& Castro (1959) emphasised that the only reliable methodology that reduces subjectivity in the designation of floristic territories is the preparation of accurate taxon distribution dot maps for the region being defined. Such maps rely on the availability of a sufficient number of specimens as well as monographic studies. Dot maps were employed in the original formulation of the PAT; some of the original maps from Prado (1991) have been reproduced here for the 
purpose of visual comparison with updated ones. The original dot maps were based on identification-verified herbarium specimens or citations in reliable taxonomic revisions (solid symbols, Fig. 4A) together with citations in reliable vegetation surveys (open symbols, Fig. 4).

Occurrence data for each legume species analysed were obtained firstly from the original hand-written specimen cards (Prado, 1991). A large quantity of additional data was obtained from the GBIF portal (data.gbif.org, March 2013), but also from relevant literature which included information on the set of species under study (Arenas, 1981; Burkart et al., 1987; Lewis, 1987; Killeen et al., 1993; Barneby \& Grimes, 1996, 1997; Mereles, 1998; Navarro \& Maldonado, 2002; Queiroz, 2009; Lewis et al., 2012). Several web portals were also consulted, including tropicos.org, ipni.org, and the websites 'Lista de Espécies da Flora do Brasil 2013' (in floradobrasil.

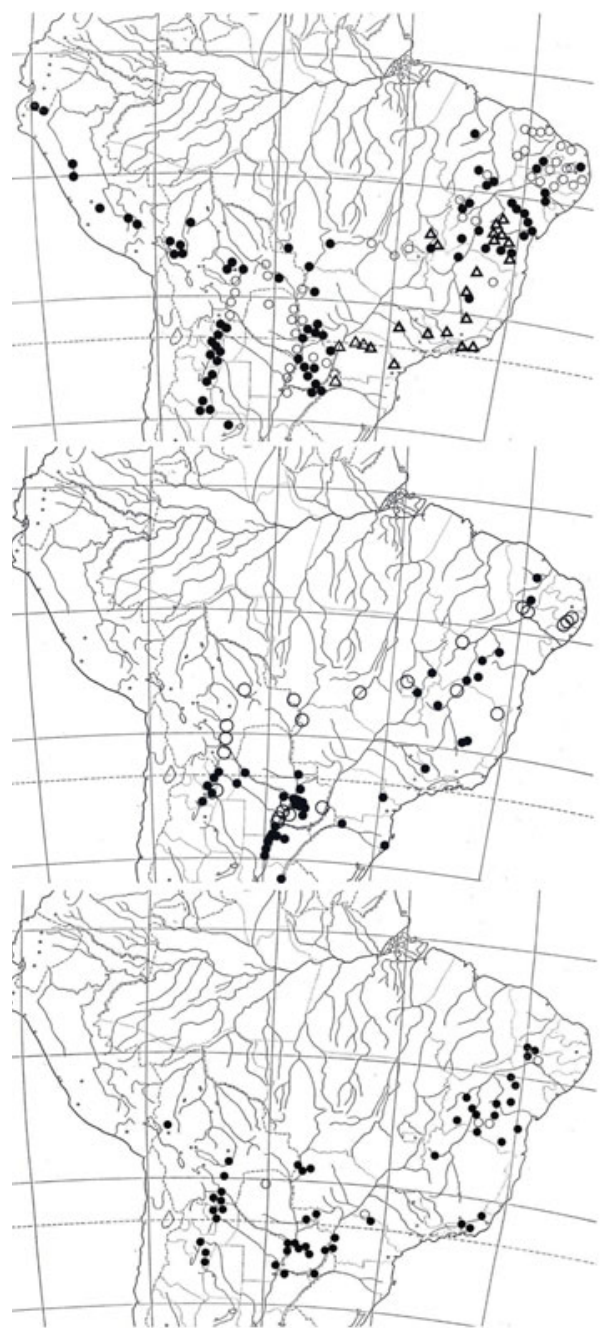

A

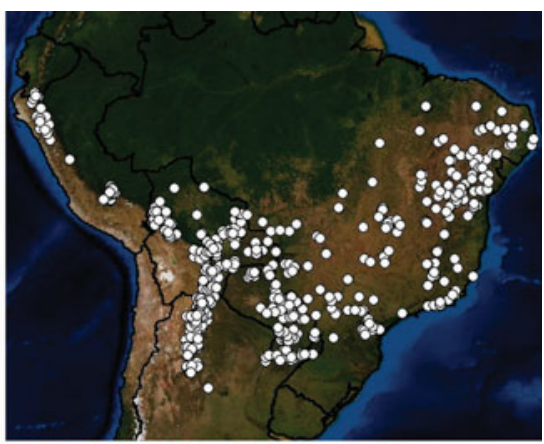

B

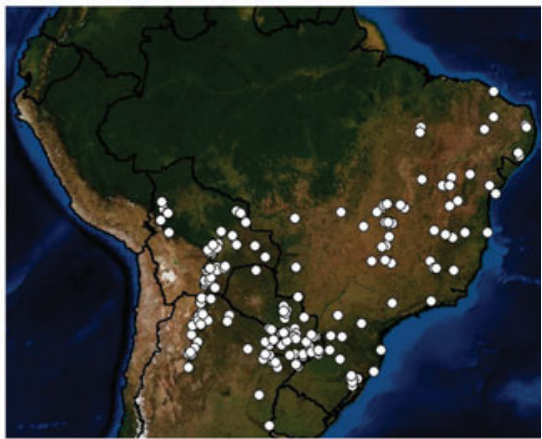

C

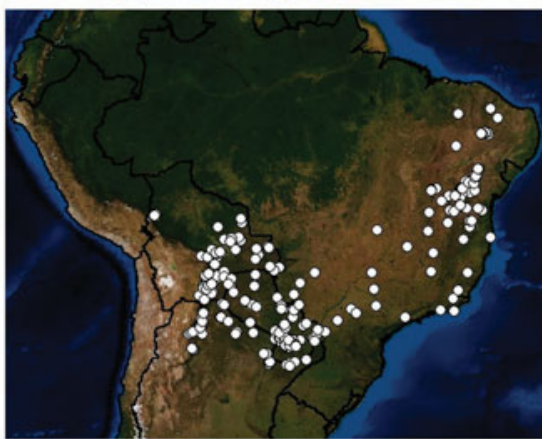


jbrj.gov.br) and 'Flora del Conosur' (darwin.edu.ar/Proyectos/FloraArgentina/ FA.asp) in order to check synonyms and the area of occupation of species.

The information gleaned from web portals (e.g. Beck et al., 2013) is of variable reliability. To overcome this, all the records obtained from web resources were checked against available taxonomic monographs. In the case of occurrences reported in web sites but not found in the literature, the image of the specimen itself was often consulted (e.g. NYBG, Tropicos, Darwinion, Kew: apps.kew.org/herbcat/navigator.do). If no images were available we only used records whose identification had been made or confirmed by international specialists. This follows the same approach used in another SDTF study (Särkinen et al., 2011).

The dataset was compiled and 'cleaned' (Hijmans et al., 2001) by comparing recorded distributions with areas noted in the literature, as well as the field experience of the authors. Obvious distribution outliers were checked and deleted when necessary and cultivated specimens were excluded from the analysis. For specimens lacking geo-reference data, coordinates were estimated using Google Earth, Google Maps and historical maps and gazetteers. DIVA GIS v7.5 (Hijmans et al., 2001) was used to construct individual and combined distribution maps.
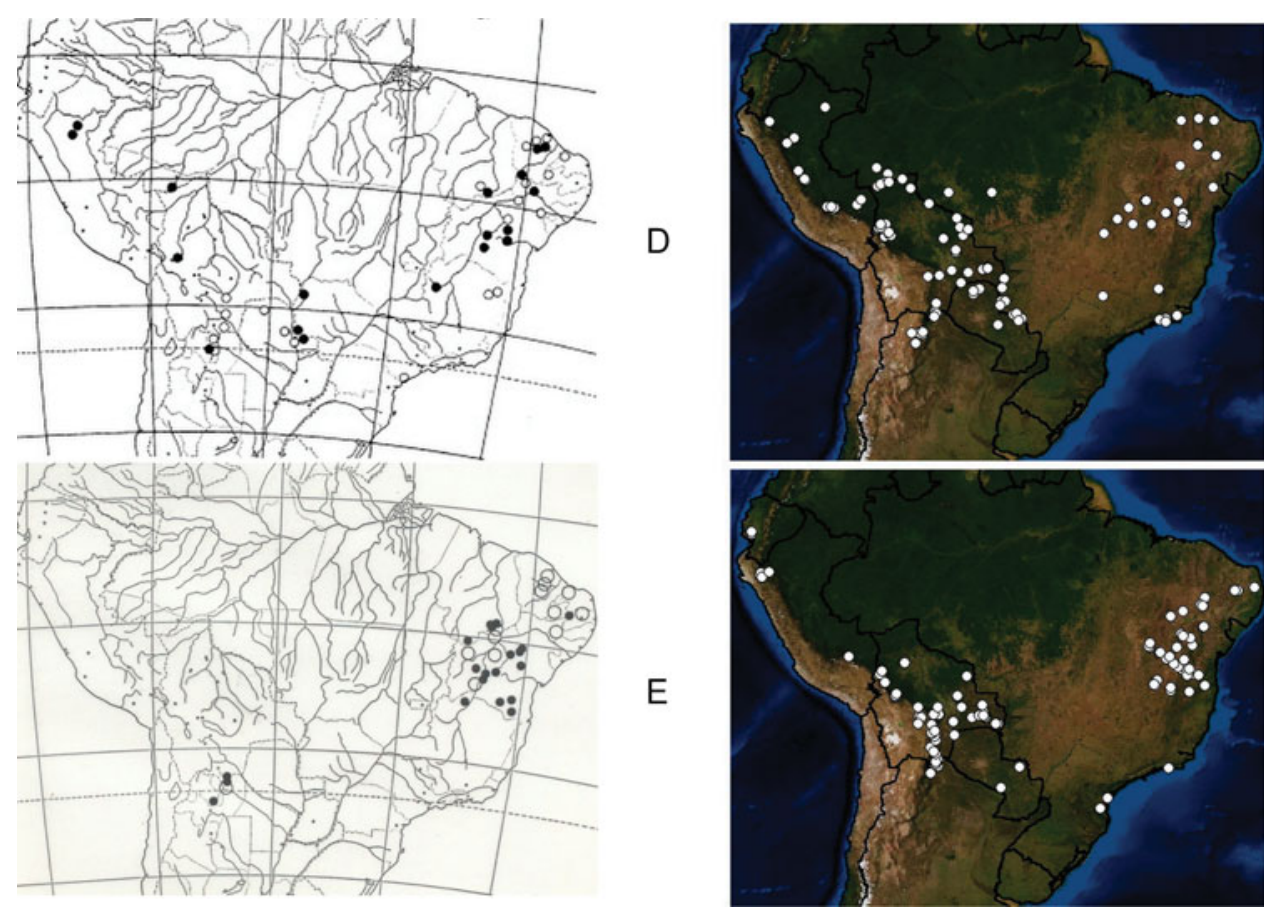

FIG. 4. Distribution maps of some selected woody Leguminosae typical of the South American SDTF. A: Anadenanthera colubrina; B: Enterolobium contortisiliquum; C: Pterogyne nitens; D: Amburana cearensis; E: Piptadenia viridiflora. On the left: as in Prado (1991); on the right, new maps. 


\section{Results And Discusion}

\section{Chaco endemics}

In South American biogeography the Gran Chaco comprises the thorny vegetation that covers the vast rolling plains of north-central Argentina, western Paraguay and south-eastern Bolivia (Fig. 1), also entering Brazil as a narrow strip following the course of the river Paraguay in Mato Grosso do Sul. It covers approximately 1,000,000 km² and consists of semi-arid forests, woodlands and occasionally savannas. To confirm the identity of the Chaco as a phytogeographical unit, a revision of its environmental characteristics (geomorphology, soils and climate) was performed (Prado, 1993a), together with a search for endemic genera and species, the latter including the preparation of dot maps of several of these taxa (Prado, 1991). The Chaco biome usually occurs on saline or alkaline soils with poor drainage and is subject to frequent flooding, particularly in the eastern sector (the so-called Humid Chaco), but decreases to the west where loamy-sandy, xeric soils are more characteristic. Severe winter frosts are very frequent and increase to the west ranging from an average of 0.3 frost days/ year and a minimum absolute temperature of $-1.5^{\circ} \mathrm{C}$ in the east to 28.9 or more frost days/year and a minimum absolute temperature of $-10^{\circ} \mathrm{C}$ in the west (Galmarini \& Raffo del Campo, 1964; Conti et al., 2009). The floristic composition is a distinctive feature of this biome with some typical tree taxa, e.g. several species of Schinopsis Engl. (Anacardiaceae), Aspidosperma quebracho-blanco Schltdl. (Apocynaceae), Tabebuia nodosa (Griseb.) Griseb. (Bignoniaceae), and several species of the genera Prosopis L., Acacia Mill. sensu lato, and Bulnesia Gay (Zygophyllaceae). The Chaco vegetation has strong floristic links with the Prepuna, Monte and some Andean formations (Cabrera, 1953, 1971; Pennington et al., 2000; Spichiger et al., 2004).

With the relatively scant information available in 1991, a total of eight endemic genera and 92 woody or succulent endemic species was noted for the Chaco. Three monotypic endemic legume genera were found (Lophocarpinia Burkart, Mimozyganthus Burkart and Stenodrepanum Harms) and 21 endemic species, eight belonging to Caesalpinioideae, 11 to Mimosoideae and only two to Papilionoideae. The most diverse genus as regards endemic species was Prosopis, with eight endemics: P. elata (Burkart) Burkart, P. fiebrigii Harms, P. hassleri Harms, P. kuntzei Harms, P. pugionata Burkart, P. rojasiana Burkart, $P$. ruscifolia Griseb. and $P$. vinalillo Stuck. Almost endemic to the Chaco but of wider distribution is Prosopis nigra (Griseb.) Hieron. that sometimes extends into neighbouring formations (Prado, 1991). This high endemism is not surprising, since the centre of diversity of the genus Prosopis includes the Chaco plains (Burkart, 1976a, 1976b; Burghardt \& Espert, 2007).

The list of Chaco endemics has grown over the past 23 years. There are now four endemic genera of Leguminosae, the additional one, Piptadeniopsis Burkart with its single shrubby species $P$. lomentifera Burkart, having been overlooked by Prado (1991). This species is restricted to central Paraguay. The phylogenetic affinities of this genus and the partially sympatric sister genus Mimozyganthus (reaffirmed as a Chaco endemic) were studied by Luckow et al. (2005), and together with Prosopidastrum 
Burkart the three genera form a monophyletic group, sister to the Leucaena group. The phylogenetic relationships of the two monotypic caesalpinioids endemic to the Chaco (Lophocarpinia and Stenodrepanum) were also studied and illustrated by Nores et al. (2012). These two genera are allopatric within the Chaco and are phylogenetically more distant from each other than the mimosoid genera; Lophocarpinia is sister to Haematoxylum L., whereas Stenodrepanum is sister and probably congeneric to the sympatric genus Hoffmannseggia Cav.

At the species level there has been considerable progress in the study of Chaco legumes; the narrow endemic Apurimacia dolichocarpa (Griseb.) Burkart is noteworthy. It was listed by Prado (1991) as a doubtful Chaco endemic and is distributed within an area of less than $400 \mathrm{~km}^{2}$ (Grossi \& Funes, 2011) in Sierra Chaco forests. Otholobium higuerilla (Gillies ex Hook.) J.W.Grimes (= Psoralea higuerilla Gillies ex Hook.) also belongs exclusively in the Sierra Chaco, although much more widely distributed than Apurimacia (Grimes, 1990). Two more endemic Prosopis species are added to the list of Chaco endemics: P. campestris Griseb. (Roig, 1993) and P. nuda Schinini (Antezana et al., 2000). In the genus Acacia (in its broad traditional sense), one new Chaco endemic species was described by Fortunato \& Cialdella (1996): A. emilioana Fortunato \& Ciald.; it is restricted to the Chaco of western Paraguay and neighbouring Bolivia. The species is now more correctly referred to Senegalia emilioana (Fortunato \& Ciald.) Seigler \& Ebinger (Seigler et al., 2006). Another Chaco endemic, Acacia curvifructa Burkart (Ebinger et al., 2000), has been confirmed in a revision of Acacia subgenus Acacia. The accepted name of this species is Vachellia curvifructa (Burkart) Seigler \& Ebinger (Seigler \& Ebinger, 2005). Also endemic to the Chaco is Chloroleucon chacoënse (Burkart) Barneby \& J.W.Grimes (Barneby \& Grimes, 1996). Finally, Caesalpinia coluteifolia Griseb. is the only entirely Chaco endemic species in the whole Poincianella-Erythrostemon group of Caesalpinia sensu lato (Ulibarri, 1996; Lewis, 1998).

\section{Caatingas endemics}

In South American biogeography the term Caatingas is employed to indicate the semi-arid vegetation that covers a large part of north-eastern Brazil (Andrade-Lima, 1981; Velloso et al., 2002), extending from eastern Piauí state, through most of Ceará and Rio Grande do Norte, western Paraíba, Pernambuco, Sergipe, Alagoas, central Bahia, and parts of northern Minas Gerais state. The Caatingas are surrounded and demarcated by the Atlantic Forest to the east and the Cerrado vegetation to the south-west (Fig. 1). They cover more than 850,000 km² (Queiroz, 2006). The vegetation consists of forests, woodlands and scrublands (see list of vegetation types in Andrade-Lima, 1981), physiognomically dominated by thorny deciduous species, mostly legumes. Species with evergreen foliage are scarce, these mainly thriving along seasonally dry riverbeds. As reported for the Chaco, to corroborate the identity of the Caatingas as a true phytogeographical unit, a revision of its environmental 
characteristics (geomorphology, soils and climate) was performed, together with a search for endemic genera and species and the preparation of taxon dot maps (Prado, 1991, 2003).

With even more scarce information available for the Caatingas flora in 1991, a total of 13 endemic genera and 183 woody or succulent endemic species was recorded. In the legume family, no endemic Caatingas genera were found. A total of 59 endemic species was recorded, 21 belonging to Caesalpinioideae, 21 to Mimosoideae and 17 to Papilionoideae (Prado, 1991). More than $50 \%$ of the 59 (32 species) were doubtfully endemic. Critical to establishing the Leguminosae list of Caatingas was the landmark work Legumes of Bahia (Lewis, 1987).

After 23 years, the list of Caatingas endemics has grown greatly. There are now four monotypic legume genera endemic to the Caatingas: Blanchetiodendron Barneby \& J.W.Grimes, Mysanthus G.P.Lewis \& A.Delgado, Tabaroa L.P.Queiroz, G.P.Lewis \& M.F.Wojc., and Goniorrhachis Taub. The genus Blanchetiodendron in the Mimosoideae was proposed by Barneby \& Grimes (1996) to accommodate B. blanchetii (Benth.) Barneby \& J.W.Grimes as separate from Albizia Durazz., where it had previously been placed by Lewis (1987) as A. blanchetii (Benth.) G.P.Lewis. Two of the endemic genera belong in the Papilionoideae; the genus Mysanthus was segregated from Phaseolus L. by Lewis \& Delgado-Salinas (1994) to accommodate its only species M. uleanus (Harms) G.P.Lewis \& A.Delgado, which had been of uncertain taxonomic position for a long time. The very narrow endemic Tabaroa caatingicola L.P.Queiroz, G.P.Lewis \& M.F.Wojc. is a recently discovered and described, critically endangered taxon occupying an area of less than $12 \mathrm{~km}^{2}$ on inland sandy soils of south-eastern Bahia (Queiroz et al., 2010). The caesalpinioid tree Goniorrhachis marginata Taub. may be endemic to the Caatingas. Most collection localities being in arboreal caatinga (Lewis, 1987; Queiroz, 2009), it is also recorded from 'seasonal forests', which sensu lato could refer to Caatingas vegetation.

The remarkable progress made in the last 23 years in neotropical legume taxonomy is evidenced by the increase in endemic taxa, which has almost tripled from the number given by Prado (1991). According to Queiroz (2006), of a total of 292 legume taxa native to the Caatingas, some 144 are endemic (almost 50\%). It should be pointed out that this is a very high percentage of endemics, comparable to that of isolated oceanic islands, a fact suggested by Pennington et al. (2000) and later supported by Prado (2003). It is unnecessary to list the new endemic taxa to the Caatingas here; they have been cogently and abundantly studied, analysed, mapped and even ecologically characterised in two exhaustive works by Queiroz $(2006,2009)$. The latter study permitted an assessment of the endemic character of the 32 doubtful taxa mentioned before and confirmed that most of them (22) are indeed endemic after a comparison of Prado's list (1991) and Queiroz's (2009) monographic study on the Caatingas legumes.

Nevertheless, the genus Luetzelburgia Harms exemplifies the complex taxonomic history of many legumes of the Caatingas. Luetzelburgia is a genus of beautiful trees rarely seen in flower, fruit and leaf at the same time (Queiroz, 2009), a phenomenon true of many Caatingas tree species, regardless of plant family. This causes an 
additional difficulty in fully understanding the SDTF flora. In 1991, at the time of the formulation of the PAT, only three species of Luetzelburgia were known to occur in the Caatingas (Lewis, 1987): L. auriculata (Allemão) Ducke, also occurring in Cerrado vegetation; the caatinga endemic L. andrade-limae H.C.Lima, and L. bahiensis Yakovlev, hesitantly added as a possible endemic by Prado (1991). Today, we know that six species of the genus occur in Caatingas (Queiroz, 2009), five of which are confirmed endemic, including the two previously listed as such. The three new endemic species were described in a recent publication (Cardoso et al., 2008): L. harleyi D.B.O.S.Cardoso, L.P.Queiroz \& H.C.Lima, L. neurocarpa D.B.O.S.Cardoso, L.P.Queiroz \& H.C.Lima, and L. purpurea D.B.O.S.Cardoso, L.P.Queiroz \& H.C.Lima. In addition, and even more recently, the same three authors have described two new species of Luetzelburgia from the SDTF of Bolivia (Cardoso et al., 2012), L. andina D.B.O.S.Cardoso, L.P.Queiroz \& H.C.Lima and L. sotoi D.B.O.S.Cardoso, L.P.Queiroz \& H.C.Lima, thus extending the range of a genus previously only known from Brazil.

\section{Pleistocene Arc Theory (PAT) distribution pattern}

The PAT pattern was discovered as a serendipitous by-product of a study of the alleged strong Chaco-Caatingas links. Originally formulated in a PhD thesis (Prado, 1991), it was formally published by Prado \& Gibbs (1993). According to the theory, a considerable number of SDTF woody species, many of them belonging to the Leguminosae, had probably been involved in the hypothesised expansion-retreat cycles and migrations that led to the current-day SDTF distribution pattern. These species are today known to be members of several tropical and subtropical deciduous forests in South America. These include the extensive Caatingas of north-eastern Brazil and also certain semi-deciduous non-Atlantic Forest formations in the states of São Paulo and Paraná, together with the forests of the Upper Uruguay river valley, most of the forests surrounding the Paraguay-Paraná river system, the Santiago and Chiquitos Sierras of south-eastern Bolivia, and the Piedmont forests in north-western Argentina and south-western Bolivia (stretching southwards from Santa Cruz de la Sierra in Bolivia, to Tucumán and Catamarca in Argentina). Elsewhere these forests are more sparsely scattered in the dry Andean valleys of northern Bolivia, across Peru and occasionally extending into south-western Ecuador. Some of the legume species in these forests are dominant. When all these species are mapped and the maps combined, the resulting compound map shows an unmistakable PAT pattern (see fig. 2 in Prado, 2000, and Fig. 2 of this study).

All these units of SDTF, and their constituent species, skirt the impoverished soils of the Brazilian Cerrado (Fig. 1) savanna vegetation (Furley \& Ratter, 1988), even to the extent of 'island-hopping' across this region by way of isolated calcareous outcrops (Ratter et al., 1978, 1988). This phenomenon has also been highlighted by several other students of the SDTF (Nascimento et al., 2004; Silva \& Scariot, 2004; 
Pereira et al., 2011). One example is the most iconic tree of the PAT, the mimosoid Anadenanthera colubrina, which comprises two varieties: var. colubrina and var. cebil (Griseb.) Altschul (Altschul, 1964). In the 1991 distribution map of this species (Prado, 1991) the varieties were mapped with different symbols (see Fig. 4A (left), open triangles for var. colubrina, solid or open circles for var. cebil), and there was some indication that the two varieties occurred in rather different regions. In the new map (Fig. 4A, right) they are not differentiated because the taxonomic characters traditionally used to distinguish them are almost impossible to apply in the field (e.g. differing leaflet venation, used by Altschul, 1964) and, contrary to the published literature, both varieties coexist in most SDTFs of northern Argentina (i.e. SDTF in Misiones, Corrientes, Formosa, Jujuy, Salta and Tucumán provinces; Martínez et al., 2013).

Anadenanthera colubrina, known as 'angico' in Brazil, or 'curupay', 'curupaú or 'cebil' in the rest of the Neotropics, is one of the more common species in the arboreal Caatingas of north-eastern Brazil (Andrade-Lima, 1981), as witnessed by the large number of collections from this region (Fig. 4A). It is more scattered across the Brazilian Cerrado, but occurs exclusively in mesophilous woodlands or mesotrophic cerradão (Ratter et al., 1978) on calcium-rich soils. The species then extends through the Misiones Nucleus of the Paraguay-Paraná river system from where there are numerous herbarium specimens and observation records, whereas the reasonably well-collected Chaco plains show an impressive absence of the species. On the western border of the Chaco there is a notable concentration of dots on Fig. 4A (right), coinciding with a narrow fringe of SDTF in the foothills of the sub-Andean sierras of north-western Argentina and south-western Bolivia, a vegetation type that has traditionally been submerged in the Yungas province (as 'Transitional Forest', Cabrera, 1971). The distribution of Anadenanthera colubrina then extends in a more scattered pattern along the dry inter-Andean valleys of north-western Bolivia and throughout Peru, reaching its ultimate north-western limit in southern Ecuador.

The distribution map (Fig. 4A, right) includes post-1991 collections together with the previously mapped ones (Prado, 1991). The original map included only 140 records (Fig. 4A, left) and the updated one includes 877 (Fig. 4A, right; Table 1). Nevertheless, in both maps of Anadenanthera colubrina (Fig. 4A), the species is nearly absent from the Chaco, thus reinforcing the lack of floristic links amongst this region, the Caatingas and the SDTF. The Cerro León area is located within the Chaco of Paraguay (at approximately $20^{\circ} 19^{\prime} 54,30^{\prime \prime} \mathrm{S}, 60^{\circ} 19^{\prime} 58,06^{\prime \prime} \mathrm{W}$ ). This massive Devonian outcrop was scarcely known until relatively recently (Ramella \& Spichiger, 1989). Although A. colubrina was mentioned by these authors as very important in the local dry forests (Ramella \& Spichiger, 1989), only one literature record of the species was included from the area in the map of Prado (1991). In our new map numerous records of $A$. colubrina have been added to the Cerro León area and nearby gallery forests (Fig. 4A, right). The slopes of the Cerro León are in fact covered with SDTF vegetation (Ramella \& Spichiger, 1989; Pennington et al., 2000). 
TA B LE 1. Comparison of number of specimen records (including literature citations) mapped in Prado (1991) vs. in this paper, for a select number of the Leguminosae species

\begin{tabular}{lll}
\hline \hline Species & Prado 1991 & Mapped in this paper \\
\hline Anadenanthera colubrina & 140 & 877 \\
Enterolobium contortisiliquum & 64 & 230 \\
Pterogyne nitens & 54 & 288 \\
Amburana cearensis & 39 & 131 \\
Piptadenia viridiflora & 34 & 151 \\
Collaea paraguariensis & - & 19 \\
Zygia morongii & - & 9 \\
Zygia pithecolobioides & - & 10 \\
Acosmium cardenasii & - & 18 \\
Steinbachiella leptoclada & - & 13 \\
\hline \hline
\end{tabular}

Differences between the original and present-day distribution maps of Anadenanthera colubrina also include increased records from the Cerrado in Brazil, and also in Paraguay, Bolivia and Peru. New records from the Brazilian Cerrado mostly correspond to calcareous rock outcrops (Ratter et al., 1978, and Fig. 4A, right). In central Paraguay there are many new records which include some intrusions into the Humid Chaco on levees with better drained soils. As stated by Spichiger et al. (2004, 2006), Paraguay can be seen as a huge ecotone in South America, at the intersection of the Chaco biome, the São Francisco Basin, and the Paraná Basin vegetation. The Chiquitanía area (Bolivian Chiquitanos SF; Fig. 1) and the north-western Andean slopes in Bolivia (Bolivian Inter-Andean Valleys SF; Fig. 1), together with the SDTF area of northern Peru, close to the frontier with Ecuador (Peruvian Eastern Andean SF; Fig. 1), likewise are now well represented by collections of $A$. colubrina.

Despite all these new records since 1991, the distribution of Anadenanthera colubrina still closely maps the original PAT pattern presented by Prado \& Gibbs (1993). This PAT distribution pattern is repeated, wholly or in part, by a number of other woody species of South American SDTF that have been mapped elsewhere (Prado \& Gibbs, 1993; Mayle, 2004). These include the leguminous trees Enterolobium contortisiliquum (Vell.) Morong, Pterogyne nitens Tul., Amburana cearensis (Allemão) A.C.Sm., and Piptadenia viridiflora (Kunth) Benth. These species are also presented in the maps of Fig. 4, as they characterise the PAT pattern.

The mimosoid Enterolobium contortisiliquum is a large conspicuous tree with indehiscent peculiarly shaped fruits. Apparently rather scarce in the Caatingas as presented in the 1991 map (Prado, 1991; Fig. 4B, left), it had been seen and collected in arboreal Caatinga by Andrade-Lima $(1975,1981)$ and also recorded infrequently from south-eastern Brazilian forests. It is frequent in the Paraguay-Paraná river system (Reboratti \& Neiff, 1986; Prado et al. 1989; Oakley et al., 2005), where it has been used traditionally as a fish poison by indigenous communities (Dujak \& Marchi, 2010). Known as 'pacará' in north-western Argentina and south-western Bolivia, where it is abundant and even dominant in parts of the sub-Andean Piedmont forests, 
it was not recorded in any dry Andean valleys until 1991 (Fig. 4B, left). It had occasionally been noted within the Chaco plains, though only in gallery forests on alluvial levees along the main rivers (Morello \& Adámoli, 1974) together with other nonchaquenian elements. In making the updated map (Fig. 4B, right), the collections of Enterolobium timbouva Mart., a species doubtfully accepted as distinct by Barneby \& Grimes (1996), have been considered by us as a synonym of E. contortisiliquum in agreement with Lewis (1987), accepted by Prado (1991), and also suggested by Queiroz (2009), who considers them possibly to be two ecotypes of the same species. The number of known records is now nearly four times that presented in the 1991 map (Table 1). This species is almost absent from the Chaco. However, in the following regions there is now a marked increase in records compared with the 1991 map: the Misiones Nucleus (which somewhat equates to the Austro-Atlantic SF; Fig. 1), the Chiquitanía (Bolivian Chiquitanos SF; Fig. 1), in the Bolivian part of the Piedmont Nucleus forests, and remarkably in the north-western Andean slopes in Bolivia (Bolivian Inter-Andean Valleys SF; Fig. 1), from which no records were available on the original 1991 map (Fig. 4B, left).

The case of Pterogyne nitens is rather peculiar, because of its somewhat invasive nature. It also has a similar distribution to the previous species, and had been reported from gallery forests within the Chaco as well (Morello \& Adámoli, 1974; Prado, 1991). The northern half of the Chaco now has numerous records of $P$. nitens (Fig. 4C, right). In several cases the appearance within the Chaco corresponds to its spontaneous presence in tall grasslands of Elionurus muticus (Spreng.) Kuntze in the Chaco of Paraguay (Ramella \& Spichiger, 1989; Mereles \& Degen, 1994; Mereles, 2005). Although native to a number of vegetation types, in some areas the tree is visibly invading new ground, such as open urban spaces in the city of Corumbá, Mato Grosso do Sul, Brazil (authors' personal observation, 2003), and vacant plots in the city of Asunción in Paraguay, and it is expanding in disturbed rural areas in southern Formosa province, Argentina (authors' personal observations). Nevertheless, P. nitens is now known to occur as a native species in SDTF of the Bolivian Chiquitanía, but is rare in the northern Bolivian Andean valleys (Fig. 4C).

Amburana cearensis is a well-documented but not abundant species of the PAT in Caatingas vegetation (arboreal and shrubby caatinga; Andrade-Lima, 1981). In the Piedmont Nucleus, it is rather scarce but a constant SDTF species (Fig. 4D). In both maps it is rare in the Cerrado. The lack of collection records in the 1991 map (Fig. 4D, left) from the southern half of the Misiones Nucleus is now updated (Fig. 4D, right). New records from Rio de Janeiro state in Brazil and the Bolivian Chiquitanía add to the overall distribution pattern. Additionally, A. cearensis is now better known from the north-western Andean slopes in Bolivia (Bolivian Inter-Andean Valleys SF; Fig. 1) and Andean Peru and north-eastern Paraguay (López Villalba et al., 2002; Oakley \& Prado, 2011). New records from neighbouring Brazil, mainly from the state of Acre, are also noteworthy (Fig. 4D).

The tree species Piptadenia viridiflora was scarcely recorded from north-western Argentina until Burkart (1952) noted it for the first time. Conversely it has long 
been a well-known component of the Caatingas (Fig. 4E). Collection records have increased fourfold since 1991. A few scattered new records from coastal south-eastern Brazil and Paraguay add to the 1991 map (Fig. 4E, right). In 1991 the species was hardly known from Bolivian Chiquitanía or more northern areas. Now P. viridiflora is known to be common in the Chiquitanía, as well as the northern dry valleys of Bolivia, and is also known to occur in northern Peruvian SDTF and southern Ecuador.

The original PAT pattern (Prado \& Gibbs, 1993) is still perfectly recognisable. The rapid growth in collection records in the past 23 years (occurrences in Table 1) has added support to the PAT. Moreover, the PAT distribution pattern is better defined and continues to be very significant because it is repeated, wholly or in part, by a number of other woody species of South American SDTF legumes (e.g. Geoffroea spinosa Jacq., and other plant families; Caetano et al., 2008).

\section{Endemism in other nuclei}

When the PAT theory was proposed as a hypothesis, the authors could not provide a list of endemic taxa in the Misiones Nucleus, nor in the Bolivian Chiquitanía, because of the lack of data from those regions at the time. In the last 23 years, these data gaps have been filled, at least for Leguminosae. For example, in the Misiones Nucleus, a number of endemic taxa have been added from a thorough review of the recent literature and the combined field knowledge of the present authors. These species had previously been overlooked, under-collected or have been described or redefined since 1991; e.g. Arachis correntina (Burkart) Krapov. \& W.C.Greg. (Krapovickas \& Gregory, 1994); Collaea paraguariensis (Hassl.) R.C.García (García, 1989) (see Fig. 5); Desmanthus hexapetalus J.F.Macbr. (Luckow, 1993); Sesbania macroptera Micheli (Gómez Sosa, 2000); Tephrosia hassleri Chodat (Vanni, 1994); Zygia morongii Barneby \& J.W.Grimes and Zygia pithecolobioides (Harms) Barneby \& J.W.Grimes (Barneby \& Grimes, 1997) (see Fig. 5). This list of species reinforces the Misiones Nucleus (e.g. Prado \& Gibbs, 1993; Spichiger et al., 2004, 2006) as a biogeographical entity.

For the Chiquitanía, there is also mounting evidence of endemism to support it as a recognisable biogeographical entity. The Chiquitanía Nucleus, as part of the PAT, is now better supported by increased legume collection data. In addition, Pennington et al. (2000), Navarro \& Maldonado (2002), Killeen et al. (2006), Linares-Palomino et al. (2011), Sánchez-Azofeifa \& Portillo-Quintero (2011) and Särkinen et al. (2011) have either mapped the Chiquitanía as a SDTF centre or provided detailed floristic lists supporting it as a valid biogeographical and floristic entity. Moreover, Werneck et al. (2011) demonstrated that the Chiquitano area has been stable for 21,000 years, and served as a refugium during the climatic fluctuations of the Pleistocene. These authors employed recent modelling techniques (e.g. BM/MAXENT) to scrutinise the SDTF paleo-distribution, and compared their results with the available palynological 

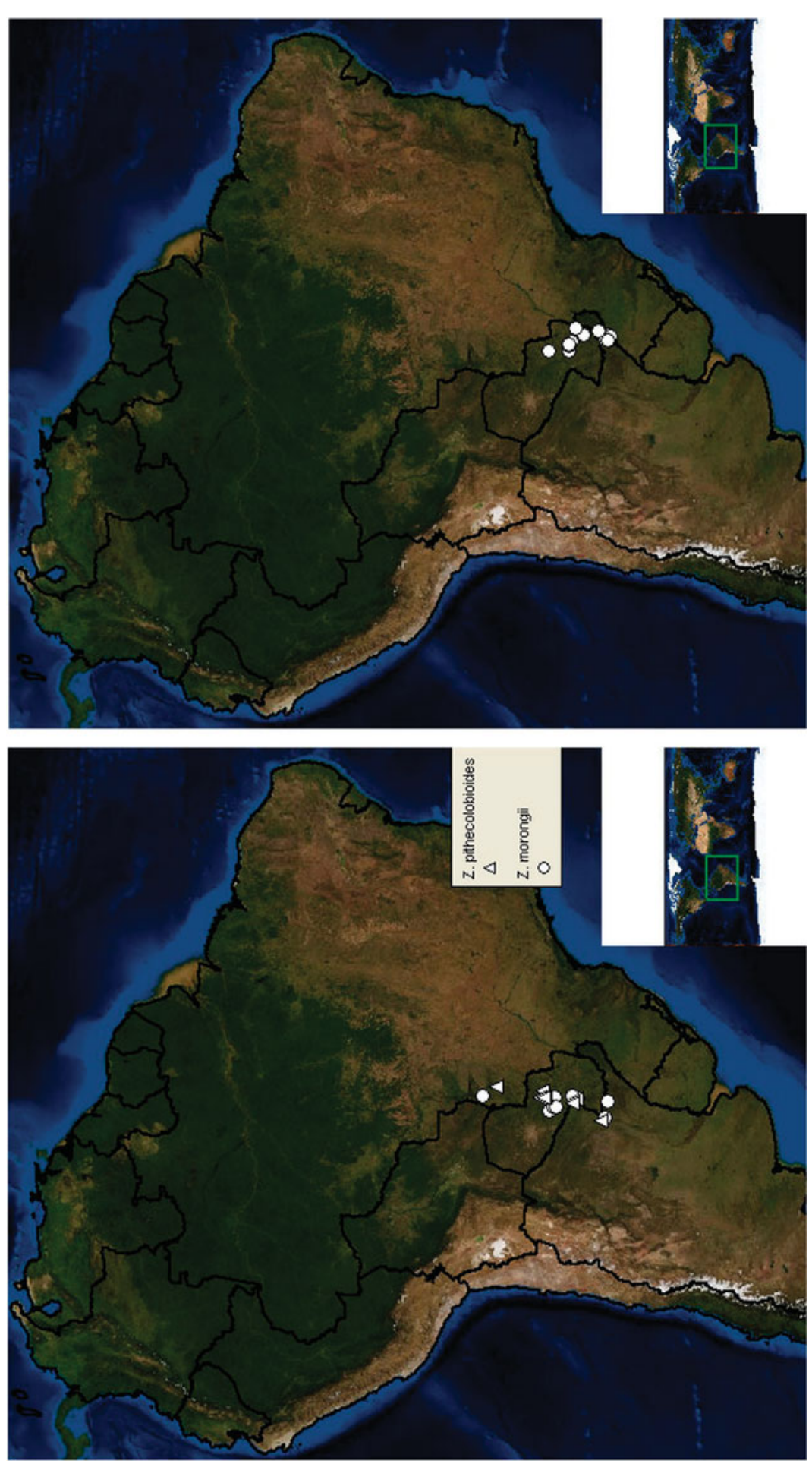
evidence. Comparing analyses of the climatic variables corresponding to the SDTF of today, 6000 years ago and the Last Glacial Maximum (LGM), the models show great stability of the original nuclei proposed for the PAT, and support the Chiquitanía as a fourth nucleus. Overlaying these model results with paleo-palynological data produced similar results, and corroborated a circum-Amazon corridor of SDTF in the recent geological past (Werneck et al., 2011).

The new Chiquitanía Nucleus presents a relatively reduced number of legume endemics so far; e.g. Acosmium cardenasii H.S.Irwin \& Arroyo (Killeen et al., 2006; Schütz Rodrigues \& Azevedo Tozzi, 2007) (see Fig. 6); Luetzelburgia sotoi D.B.O.S.Cardoso, L.P.Queiroz \& H.C.Lima (Cardoso et al., 2012); Steinbachiella leptoclada Harms (Lewis et al., 2012) (see Fig. 6), and Swartzia jorori Harms (Killeen et al., 2006). To these species can be added an endemic species of Cactaceae: Cereus tacuaralensis Cárdenas (Killeen et al., 2006), and a species of Malvaceae: Pseudobombax pulchellum Carv.-Sobr. (Carvalho-Sobrinho et al., 2013). Another new feature of the Chiquitanía Nucleus inferred from Navarro et al. (2006) are similar dry forests cited under the misleading name of 'cerradones' in northern Paraguay. Thus, the Chiquitano Nucleus extends further south than previously recorded (Fig. 1).

\section{CONCLUSIONS}

More than 20 years since the formulation of the Pleistocene Arc Theory, the Chaco and the Caatingas provinces are confirmed as distinct phytogeographical entities. The numbers of endemic legume genera and species records in both nuclei have increased. The increase in novelties recorded from the Chaco come mainly from previously under-explored Paraguayan Chaco.

The original PAT distribution pattern (Prado \& Gibbs, 1993) is still clearly visible and recognisable in the new taxon maps prepared for this study. The PAT pattern has also been independently confirmed by more objective techniques using similar sets of species (Spichiger et al., 2004, 2006). A new area of endemism in the Pleistocene Arc is added: the Chiquitanía Nucleus in south-eastern Bolivia and bordering Paraguay, which is supported by recent vegetation modelling (Werneck et al., 2011; Collevatti et al., 2013).

Naturally, there are a number of species that do not follow the PAT distribution pattern, which were not included in the present analysis as those additional analyses were beyond the scope of this paper. Prado (2003, p. 50) has described several different distribution patterns for SDTF species, of which the PAT pattern is just one, although one that we stress is very consistent.

Phylogenetic studies of SDTF taxa (particularly at genus level) reviewed by Pennington et al. (2004) demonstrated that speciation primarily occurred well before or at the beginning of the Pleistocene in South America. Nevertheless, according to these authors this evidence did not refute the possibility of a more widespread 


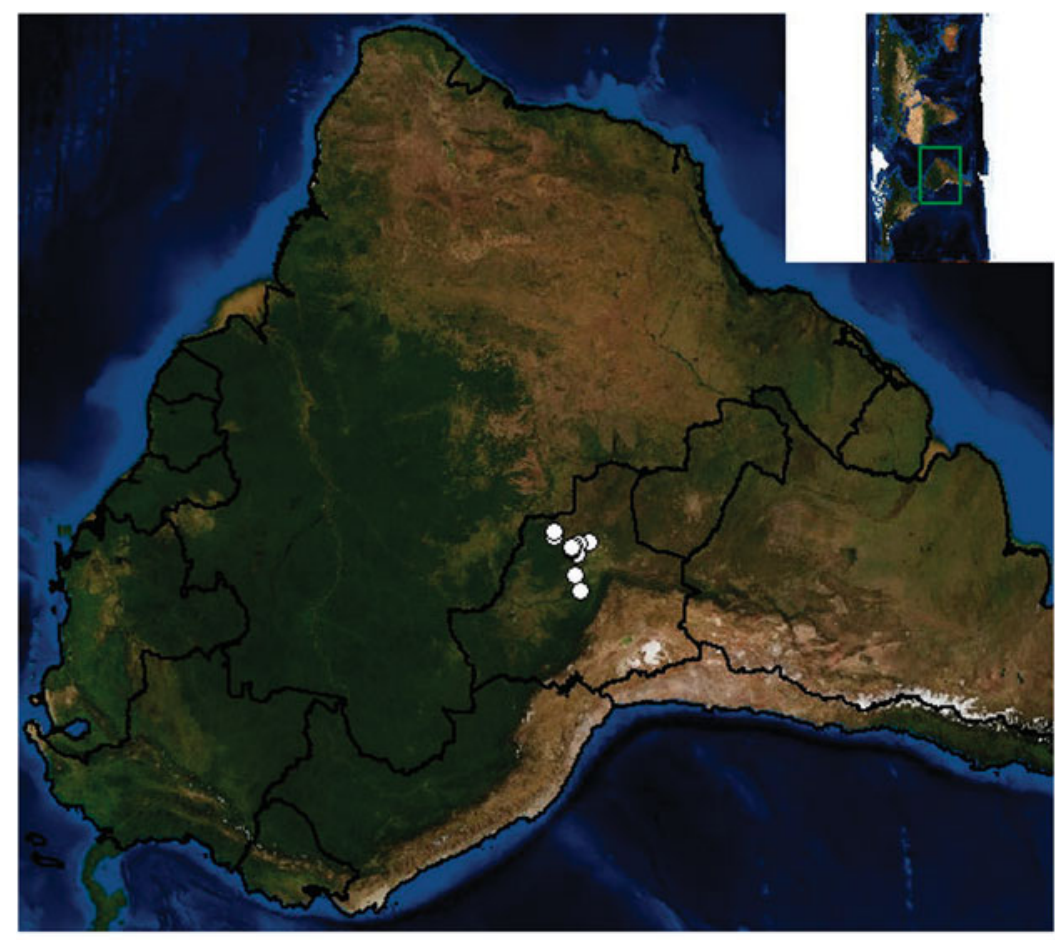

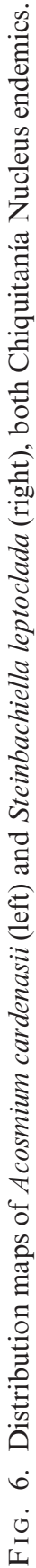


SDTF formation. In the case of widespread species (e.g. Anadenanthera colubrina, Enterolobium contortisiliquum) that show a strong PAT pattern, perhaps the period of isolation between the SDTF nuclei has not been long enough to promote speciation, but has been long enough to produce genetic variability. Population genetics studies are still very scarce (e.g. Caetano et al., 2008; Collevatti et al., 2012) and the only one published for the Leguminosae to date covers a relatively small part of the total distribution range of Anadenanthera colubrina (Barrandeguy et al., 2014).

The vicariance or long-distance dispersal debate to explain the PAT pattern (Pennington et al., 2000 vs. Mayle, 2004) remains. Probably, the historical biogeographical processes that had shaped the SDTFs as we currently know them involved a combination of long-distance dispersal and vicariance in response to past environmental shifts. Recent evidence from phylogeographic and population genetics studies suggests that long-distance dispersal, perhaps by oceanic and wind currents, and/or by bird dispersal (Renner, 2004), is much more common than previously noted, and this phenomenon may have an important role in explaining the present distribution of many taxa in neotropical rain forests (Pennington \& Dick, 2004; Dick \& Heuertz, 2008). In neotropical seasonally dry forests (SDTF), population migration and long-distance dispersal (Mayle, 2004; Linares-Palomino et al., 2011) may have occurred throughout the Cerrado and the Chaco, via smaller peripheral areas of SDTF on calcareous soils, although there is no strong molecular evidence for this.

On the contrary, some works (e.g. Caetano, 2008; Caetano et al., 2008; Collevatti et al., 2012; Barrandeguy et al., 2014) present results that support, albeit partially, the PAT hypothesis. Moreover, evidence from other SDTF nuclei in the Americas (Fig. 1) provide a strong indication of phylogenetic geographic structure, with sister species cohabiting similar areas, for example in legumes of South American dry inter-Andean valleys (Pennington et al., 2009) and in Mesoamerican Bursera species (De-Nova et al., 2012). In addition, a high beta diversity in Bursera (De-Nova et al., 2012), and in the woody plant species of the SDTFs as a whole (Linares-Palomino et al., 2011), has been recorded. This high phylogenetic geographic structure is apparently not repeated in Amazonian rain forests (Pennington et al., 2009; Dick \& Pennington, 2012), probably reflecting the fact that dispersal is more important in shaping tropical rain forest communities (Pennington \& Dick, 2004) than fragmented SDTFs (Pennington et al., 2010; Dick \& Pennington, 2012). The present-day fragmented distribution pattern of SDTF is most likely a vestige of a more continuous SDTF formation and the PAT can still confidently be tested against the long-distance dispersal hypothesis. One way to resolve the vicariance vs. long-distance dispersal debate as regards the present distribution pattern of the South American SDTFs may be to carry out population genetics and phylogeographic studies of the emblematic PAT species that we discuss in this work. 


\section{ACKNOWLEDGEMENTS}

The authors thank the National University of Rosario, Argentina, for funding and facilities to perform this work. D. Prado and V. Mogni also thank the Consejo Nacional de Investigaciones Científicas y Técnicas. Particular thanks to the AVE Program (Programa de Ayuda Viajes al Exterior, Docente) of the National University of Rosario, for providing funding to the senior author to travel to Johannesburg to the 6th International Legume Conference. Thanks are due to Agr. Luciano Galetti for his meticulous help in the preparation of legume inventories, and also to Libr. Mariela Mejorada for scanning the maps. We also thank Kyle Dexter and Toby Pennington for critical reading of a previous version of this manuscript, improving it with valuable comments and suggestions, and two anonymous reviewers for their very helpful and constructive comments.

\section{REFERENCES}

A в'S Á ber, A. N. (1957). Conhecimentos sobre as flutuações climáticas do Quaternário no Brasil. Bol. Soc. Bras. Geol. 6: 41-48.

A в'SÁB Ber, A. N. (1977). Espaços ocupados pela expansão dos climas secos na América do Sul, por ocasião dos períodos glaciais quaternários. Paleoclimas 3: 1-19.

Ав'SÁBer, A. N. (1982). The paleoclimate and paleoecology of Brazilian Amazonia. In: Prance, G. T. (ed.) Biological Diversification in the Tropics, pp. 41-59. New York: Plenum Press.

A в'SÁBer, A. N. (2000). Spaces occupied by the expansion of dry climates in South America during the Quaternary Ice Ages. Rev. Inst. Geol. 21: 71-78.

Altschul, S. V. R. (1964). A taxonomic study of the genus Anadenanthera. Contr. Gray Herb. 193: 1-65.

Andrade-Lima, D. (1975). Vegetation of the Río Grande Basin, Bahia, Brazil. Preliminary note. Rev. Brasil. Biol. 35: 223-232.

Andrade-Lima, D. (1981). The Caatingas dominium. Rev. Brasil. Bot. 4: 149-163.

Antezana, C., Atahuachi, M., Arrázola, S., Fernández, E. \& Navarro, G. (2000). Ecología y biogeografía del género Prosopis (Mimosaceae) en Bolivia. Rev. Bol. Ecol. 8: 25-36.

Arenas, P. (1981). Etnobotánica Lengua-Maskoy. Buenos Aires: Fundación para la Educación, la Ciencia y la Cultura.

Barneby, R. C. \& Grimes, J. W. (1996). Silk Tree, Guanacaste, Monkey's Earring: A Generic System for the Synandrous Mimosaceae of the Americas, Part I. Abarema, Albizia, and Allies. Mem. New York Bot. Gard. 74(1): 1-272.

Barneby, R. C. \& Grimes, J. W. (1997). Silk Tree, Guanacaste, Monkey's Earring: A Generic System for the Synandrous Mimosaceae of the Americas, Part II. Pithecellobium, Cojoba, and Zygia. Mem. New York Bot. Gard. 74(2): 1-149.

Barrandeguy, M. E., García, M. V., Prinz, K., Rivera Pomar, R. \& Fin Keldey, R. (2014). Genetic structure of disjunct Argentinean populations of the subtropical tree Anadenanthera colubrina var. cebil (Fabaceae). Plant Syst. Evol. (online) DOI:10.1007/s00606-014-0995-y.

Beck, J., Ballesteros-Mejia, L., Nagel, P. \& Kitching, I. J. (2013). Online solutions and the 'Wallacean shortfall': what does GBIF contribute to our knowledge of species' ranges? Divers. Distrib. 19: 1043-1050. 
Braun-Blanquet, J. (1919). Essai sur les notions d'élément et de territoire phytogéographique. Arch. Sci. Phys. Nat. 5e pér. 1: 497-512.

Burghardt, A. D. \& Espert, S. M. (2007). Phylogeny of Prosopis (Leguminosae) as shown by morphological and biochemical evidence. Austral. Syst. Bot. 20: 332-339.

BUR KART, A. (1952). Las Leguminosas argentinas silvestres y cultivadas. Buenos Aires: ACME Agency.

Burk art, A. (1976a). A monograph of the genus Prosopis (Leguminosae, subfam. Mimosoideae). J. Arnold Arbor. 57: 217-249.

Burkart, A. (1976b). A monograph of the genus Prosopis (Leguminosae, subfam. Mimosoideae). J. Arnold Arbor. 57: 450-525.

Burkart, A., Troncoso de Burkart, N. S. \& Bacigalupo, N. M. (1987). Flora Ilustrada de Entre Ríos (Argentina). Parte III, Dicotiledóneas Arquiclamídeas, A: Salicales a Rosales (incluso Leguminosas). Colecc. Ci. Inst. Tecnol. Agropecu. 6(3): 1-763.

Cabrera, A. L. (1953). Esquema fitogeográfico de la República Argentina. Rev. Mus. La Plata, Secc. Botánica 8: 87-168.

Cabrera, A. L. (1971). Fitogeografía de la República Argentina. Bol. Soc. Argent. Bot. 14: $1-42$.

Cabrera, A. L. \& Willink, A. (1980). Biogeografía de América Latina, 2nd edition. Washington: Secretaría General de la Organización de los Estados Americanos.

Cantano, S. (2008). Insights on the history of Seasonally Dry Tropical Forests in South America: inferences from the genetic structure of the trees Astronium urundeuva (Anacardiaceae) and Geoffroea spinosa (Fabaceae). $\mathrm{PhD}$ thesis, University of Geneva.

Caetano, S., Prado, D. E., Pennington, R. T., Beck, S. G., Oliveira-Filho, A., Spichiger, R. \& Naciri, Y. (2008). The history of Seasonally Dry Tropical Forests in eastern South America: inferences from the genetic structure of the tree Astronium urundeuva (Anacardiaceae). Molec. Ecol. 17: 3147-3159.

Cain, S. A. \& Castro, G. M. O. (1959). Manual of Vegetation Analysis. New York: Harper \& Bros.

Cardoso, D. B. O. S., Queiroz, L. P. \& Lima, H. C. (2008). Three new species of Luetzelburgia (Leguminosae, Papilionoideae) from the caatinga of Bahia, Brazil and an identification key to all species of the genus. Kew Bull. 63: 289-300.

Cardoso, D. B. O. S., Queiroz, L. P. \& Lima, H. C. (2012). Two new species of Luetzelburgia (Leguminosae, Papilionoideae) from the Seasonally Dry Tropical Forests of Bolivia. Syst. Bot. 37: 677-683.

Carvalho-Sobrinho, J. G., De Queiroz, L. P. \& Alverson, W. S. (2013).

Reinterpretation of the nomenclatural type of Pseudobombax heteromorphum (Malvaceae, Bombacoideae) reveals an overlooked new species from Bolivia. PhytoKeys 21: 53-61.

Collevatti, R. G., Terribile, L. C., Lima-Ribeiro, M. S., Nabout, J. C., de Oliveira, G., Rangel, T. F., Rabelo, S. G. \& Diniz-Filho, J. A. F. (2012). A coupled phylogeographical and species distribution modelling approach recovers the demographical history of a Neotropical seasonally dry forest tree species. Molec. Ecol. 21: $5845-5863$.

Collevatti, R. G., Terribile, L. C., de Oliveira, G., Lima-Ribeiro, M. S., Nabout, J. C., Rangel, T. F. \& Diniz-Filho, J. A. F. (2013). Drawbacks to palaeodistribution modelling: the case of South American seasonally dry forests. J. Biogeogr. 40: 345-358.

Conti, H., Cazenave, G. \& Giagnoni, R. (2009). Características Climáticas de las Provincias de Santiago del Estero, Chaco y Formosa. In: Molina, A. (ed.) Flora Chaqueña, Asteraceae. Colecc. Ci. Inst. Tecnol. Agropecu. 23(2): 9-26. 
Davis, C. C., Bell, C. D., Mathews, S. \& Donoghue, M. J. (2002). Laurasian migration explains Gondwanan disjunctions: evidence from Malpighiaceae. Proc. Natl. Acad. Sci. Biol. 99: 6833-6837.

De-Nova, J. A., Medina, R., Montero, J. C., Weeks, A., Rosell, J. A., Olson, M. E., Eguiarte, L. E. \& Magallón, S. (2012). Insights into the historical construction of species-rich Mesoamerican seasonally dry tropical forests: the diversification of Bursera (Burseraceae, Sapindales). New Phytol. 193: 276-287.

Dick, C. W. \& Heuertz, M. (2008). The complex biogeographic history of a widespread tropical tree species. Evolution 62: 2760-2774.

Dick, C. W. \& Pennington, R. T. (2012). Molecular systematic perspectives on biome origins and dynamics. New Phytol. 193: 9-11.

Dirzo, R., Young, H. S., Mooney, H. A.\& Ceballos, G. (2011). Seasonally Dry Tropical Forests: Ecology and Conservation. Washington: Island Press.

Dujak, M. \& Marchi, P. (2010). Plantas utilizadas como barbasco por algunas comunidades indígenas del Paraguay. Steviana 2: 31-44.

Ebinger, J. E., Seigler, D. S. \& Clarke, H. D. (2000). Taxonomic revision of South American species of the genus Acacia subgenus Acacia (Fabaceae: Mimosoideae). Syst. Bot. 25: 588-617.

Fortunato, R. H. \& Cialdella, A. M. (1996). Una especie nueva del género Acacia (Acacieae, Mimosoideae, Fabaceae) para el Chaco boliviano-paraguayo: A. emilioana Fortunato \& Ciald. Discusión sobre su ubicación infragenérica. Contribución al estudio de la flora y vegetación del Chaco, X. Candollea 51: 215-224.

Furley, P. A. \& Ratter, J. A. (1988). Soil resources and plant communities of the central Brazilian cerrado and their development. J. Biogeogr. 15: 97-108.

Galmarini, A. \& RafFo del CAmpo, J. (1964). Rasgos fundamentales que caracterizan el clima de la región Chaqueña. Buenos Aires: CONADE.

García, R. C. A. (1989). Una novedad en el género Collaea (Fabaceae: Phaseoleae). Bol. Soc. Argent. Bot. 26: 136-137.

Giulietti, A. M., Conceição, A. \& Queiroz, L. P. (2006). Diversidade e caracterização das Fanerógamas do semi-árido brasileiro. Recife: Instituto do Milênio do Semi-árido.

Gómez Sosa, E. V. (2000). Fabaceae, parte 10. Tribu XI. Millettieae. Tribu XII.

Robinieae. Tribu XIII. Indigofereae. Fl. Fanerog. Argent. 68: 3-30.

Grimes, J. W. (1990). A revision of the New World species of Psoraleeae (Leguminosae: Papilionoideae). Mem. New York Bot. Gard. 61: 1-114.

Grossi, M. \& Funes, G. (2011). Biología de especies australes: Apurimacia dolichocarpa (Griseb.) Burkart (Papilionoideae-Leguminosae). Kurtziana 36: 47-52.

Hijmans, R. J., Guarino, L., Cruz, M. \& Rojas, E. (2001). Computer tools for spatial analysis of plant genetic resources data: 1. DIVA-GIS. Plant Genetic Resources Newsletter 127: 15-19.

Hueck, K. (1978). Los bosques de Sudamérica. Eschborn: Sociedad Alemana de Cooperación Técnica (GTZ).

Hueck, K. \& Siebert, P. (1981). Vegetationskartev Südamerika, 2nd edition. Stuttgart: G. Fischer-Verlag.

JANZEN, D. H. (1988). Tropical dry forests: the most endangered major tropical ecosystem. In: Wilson, E. O. (ed.) Biodiversity, pp. 130-137. Washington: National Academy Press.

Killeen, T. J., García Estigarribia, E. \& Beck, S. G. (1993). Guía de Árboles de Bolivia. La Paz: Herbario Nacional de Bolivia, Missouri Botanical Garden.

Killeen, T. J., Chavez, E., Peña-Claros, M., Toledo, M., Arroyo, L., Caballero, J., ET AL. (2006). The Chiquitano dry forest, the transition between humid 
and dry forest in eastern lowland Bolivia. In: Pennington, R. T., Lewis, G. P. \& R atter, J. A. (eds) Neotropical Savannas and Seasonally Dry Forests: Plant Diversity, Biogeography, and Conservation, pp. 213-233. Boca Raton: CRC Press.

Krapovickas, A. \& Gregory, W. C. (1994). Taxonomía del género Arachis (Leguminosae). Bonplandia 8: 1-186.

Lavin, M., Schrire, B. D., Lewis, G., Pennington, R. T., Delgado-Salinas, A., Thulin, M., ET al. (2004). Metacommunity processes rather than continental tectonic history better explain geographically structured phylogenies in legumes. Philos. Trans. R. Soc. London B 359: 1509-1522.

Lewis, G. P. (1987). Legumes of Bahia. Kew: Royal Botanic Gardens.

Lewis, G. P. (1998). Caesalpinia: A revision of the Poincianella-Erythrostemon group. Kew: Royal Botanic Gardens.

Lewis, G. P. \& Delgado-Salinas, A. (1994). Mysanthus, a new genus in tribe Phaseoleae (Leguminosae: Papilionoideae) from Brazil. Kew Bull. 49: 343-351.

Lewis, G. P., Wood, J. R. I. \& Lavin, M. (2012). Steinbachiella (Leguminosae: Papilionoideae: Dalbergieae), endemic to Bolivia, is reinstated as an accepted genus. Kew Bull. 67: 1-8.

Linares-Palomino, R., Oliveira-Filho, A. T. \& Pennington, R. T. (2011). Neotropical seasonally dry forests: diversity, endemism, and biogeography of woody plants. In: Dirzo, R., Young, H. S., Ceballos, G. \& Mooney, H. A. (eds) Seasonally Dry Tropical Forests: Ecology and Conservation, pp. 3-21. Washington: Island Press.

López Villalba, J. A, Little, E. L. Jr., Ritz, G. F., Rombold, J. S. \& Hahn, W. J. (2002). Árboles comunes del Paraguay. Nande Yvyra Mata Kuera, 2nd edition. Asunción: UNA-Cuerpo de Paz.

Luck ow, M. (1993). Monograph of Desmanthus (Leguminosae-Mimosoideae). Syst. Bot. Monogr. 38: 1-166.

Luckow, M., Fortunato, R. H., Sede, S. \& Livinultz, T. (2005). The phylogenetic affinities of two mysterious monotypic mimosoids from southern South America. Syst. Bot. 30: 585-602.

Martínez, O. G., Barrandeguy, M. E., García, M. V., Cacharani, D. A. \& Prado, D. E. (2013). Presencia de Anadenanthera colubrina var. colubrina (Fabaceae, Mimosoideae) en Argentina. Darwiniana NS 1(2): 279-288.

MAyle, F. E. (2004). Assessment of the Neotropical dry forest refugia hypothesis in the light of palaeoecological data and vegetation model simulations. J. Quaternary Sci. 19: 713-720.

Mereles, F. (1998). Etude de la flore et de la végétatión de la mosaïque foret-savane palmeraie dans le Chaco Boreal, Paraguay. Thése de Doctorat, Faculté des Sciences, Université de Genéve, Switzerland.

Mereles, F. (2005). Una aproximación al conocimiento de las formaciones vegetales del Chaco Boreal, Paraguay. Rojasiana 6: 5-48.

Mereles, F. \& Degen, R. (1994). Contribución al estudio de la flora y la vegetación del Chaco boreal paraguayo. Rojasiana 1: 36-38.

Mooney, H. A., Bullock, S. H.\& Medina, E. (1995). Introduction. In: Bullock, S. H., Mooney, H. A. \& Medina, E. (eds) Seasonally Dry Tropical Forests, pp. 1-8. Cambridge: Cambridge University Press.

Morello, J. \& AdÁmoli, J. (1974). Las grandes unidades de vegetación y ambiente del Chaco argentino. Parte II. Provincia del Chaco. Buenos Aires: Serie Fitogeográfica del INTA. 
Nascimento, A. R. T., Felfili, J. M. \& Meirelles, E. M. (2004). Florística e estrutura da comunidade arbórea de um remanescente de Floresta Estacional Decidual de encosta, Monte Alegre, GO, Brasil. Acta Bot. Brasil. 18: 659-669.

Navarro, G. \& Maldonado, M. (2002). Geografía Ecológica de Bolivia: Vegetación y Ambientes Acuáticos. Cochabamba: Centro de Ecología Simón Patiño.

Navarro, G., Molina, J. \& Pérez de Molas, L. (2006). Classification of the forests of the northern Paraguayan Chaco. Phytocoenologia 36: 473-508.

Nores, M. J., Simpson, B. B., Hick, P., Anton, A. M. \& Fortunato, R. H. (2012). The phylogenetic relationships of four monospecific caesalpinioids (Leguminosae) endemic to southern South America. Taxon 61: 790-802.

OAkley, L. J. \& Prado, D. E. (2011). El Dominio de los Bosques Secos Estacionales Neotropicales y la presencia del Arco Pleistocénico en la República del Paraguay. Rojasiana 10(1): 55-75.

Oakley, L. J., Prado, D. E. \& Adámoli, J. (2005). Aspectos biogeográficos del corredor fluvial Paraguay-Paraná. Misc. Insugeo 14: 245-258.

Pennington, R. T. \& Dick, C. W. (2004). The role of immigrants in the assembly of the South American rainforest tree flora. Philos. Trans. R. Soc. London B 359: $1611-1622$.

Pennington, R. T., Prado, D. E. \& Pendry, C. (2000). Neotropical seasonally dry forests and Quaternary vegetation changes. J. Biogeogr. 27: 261-273.

Pennington, R. T., Lavin, M., Prado, D. E., Pendry, C. A., Pell, S. \& Butter worth, C. (2004). Historical climate change and speciation: Neotropical seasonally dry forest plants show patterns of both Tertiary and Quaternary diversification. Philos. Trans. R. Soc. London B 359: 515-538.

Pennington, R. T., Lewis, G. P. \& Ratter, J. A. (eds) (2006). Neotropical Savannas and Seasonally Dry Forests: Plant Diversity, Biogeography, and Conservation. Boca Raton: CRC Press.

Pennington, R. T., Lavin, M. \& Oliveira-Filho, A. T. (2009). Woody plant diversity, evolution, and ecology in the tropics: perspectives from seasonally dry tropical forests. Annu. Rev. Ecol. Evol. Syst. 40: 437-457.

Pennington, R. T., Lavin, M., Särkinen, T., Lewis, G. P., Klitgaard, B. B. \& Hughes, C. E. (2010). Contrasting plant diversification histories within the Andean biodiversity hotspot. Proc. Natl. Acad. Sci. USA 107: 13783-13787.

Pereira, B. A. S., Venturoli, F. \& Carvalho, F. A. (2011). Florestas estacionais no cerrado: uma visão geral. Pesq. Agropec. Trop. 41: 446-455.

Prado, D. E. (1991). A critical evaluation of the floristic links between Chaco and Caatingas vegetation in South America. PhD thesis, University of St Andrews, Scotland.

Pr Ado, D. E. (1993a). What is the Gran Chaco vegetation in South America?

I. A review. Contribution to the study of flora and vegetation of the Chaco, V. Candollea 48: $145-172$.

Prado, D. E. (1993b). What is the Gran Chaco vegetation in South America? II. A redefinition. Contribution to the study of flora and vegetation of the Chaco, VII. Candollea 48: 615-629.

PRADO, D. E. (2000). Seasonally dry forests of tropical South America: from forgotten ecosystem to a new phytogeographic unit. Edinburgh J. Bot. 57: 437-461.

Prado, D. E. (2003). As Caatingas da América do Sul. In: Leal, I. R., Tabarelli, M. \& Silva, J. M. C. (eds) Ecologia e conservação da Caatinga, pp. 3-73. Recife: Editora Universitária UFPE.

Prado, D. E. \& Gib Bs, P. E. (1993). Patterns of species distributions in the dry seasonal forests of South America. Ann. Missouri Bot. Gard. 80: 902-927. 
Prado, D. E., Franceschi, E. A. \& Bianchi, M. B. (1989). El bosque del escarpe occidental del Río Paraná (Argentina): Composición florística y estructura. Acta Bot. Brasil. 3: 99-108.

Queiroz, L. P. (2006). The Brazilian Caatinga: phytogeographical patterns inferred from distribution data of the Leguminosae. In: Pennington, R. T., Lewis, G. P. \& R Atter, J. A. (eds) Neotropical Savannas and Seasonally Dry Forests: Plant Diversity, Biogeography, and Conservation, pp. 121-157. Boca Raton: CRC Press.

Queiroz, L. P. (2009). Leguminosas da Caatinga. Feira de Santana: Universidade Estadual de Feira de Santana.

Queiroz, L. P., Lewis, G. P. \& Wojciechowski, M. F. (2010). Tabaroa, a new genus of Leguminosae tribe Brongniartieae from Brazil. Kew Bull. 65: 189-203.

Ramella, L. \& Spichiger, R. (1989). Interpretación preliminar del medio físico y de la vegetación del Chaco Boreal. Contribución al estudio de la flora y de la vegetación del Chaco, I. Candollea 44: 639-680.

Ratter, J. A., Askew, G., Montgomery, R. \& Gifford, D. R. (1978). Observations on forests of some mesotrophic soils in central Brazil. Rev. Brasil. Bot. 1: 47-58.

Ratter, J. A., Pott, A., Pott, V. J., da Cunha, C. N.\& Haridasan, M. (1988). Observations on woody vegetation types in the Pantanal and at Corumbá, Brazil. Notes Roy. Bot. Gard. Edinburgh 45: 503-525.

Reboratti, H. J. \& Neiff, J. J. (1986). Los bosques fluviales del Chaco oriental; primera aproximación. Amb. Subtrop. 1: 36-46.

Renner, S. (2004). Plant dispersal across the tropical Atlantic by wind and sea currents. Int. J. Plant. Sci. 165 (4 Suppl.): S23-S33.

Rizzini, C. T. (1963). Nota prévia sobre a divisão fitogeográfica do Brasil. Rev. Brasil. Geogr. 25: 3-64.

Roig, F. A. (1993). Informe nacional para la selección de germoplasma en especies de Prosopis de la República Argentina. In: Roig, F. A., Cavagnaro, J. B. \& Trione, S. O. (eds) Contribuciones Mendocinas a la Quinta Reunión Regional para América Latina y el Caribe de la Red de Forestación del CIID. Conservación y mejoramiento de especies del género Prosopis, pp. 1-36. Mendoza: IADIZA-CRICYT-CIID.

Rymer, P. D., Dick, C. W., Vendramin, G., Buonamici, A. \& Boshier, D. (2013). Recent phylogeographic structure in a widespread 'weedy' Neotropical tree species, Cordia alliodora (Boraginaceae). J. Biogeogr. 40: 693-706.

Sánchez-Azofeifa, G. A. \& Portillo-Quintero, C. (2011). Extent and drivers of change of Neotropical Seasonally Dry Forests. In: Dirzo, R., Young, H. S., Ceballos, G. \& Mooney, H. A. (eds) Seasonally Dry Tropical Forests: Ecology and Conservation, pp. 45-57. Washington: Island Press.

Särkinen, T., Iganci, J. R. V., Linares-Palomino, R., Simon, M. F. \& PRADO, D. E. (2011). Forgotten forests - issues and prospects in biome mapping using Seasonally Dry Tropical Forests as a case study. BMC Ecol. 11: 27.

Schrire, B. D., Lavin, M. \& Lewis, G. P. (2005a). Global distribution patterns of the Leguminosae: insights from recent phylogenies. Biol. Skr. 55: 375-422.

Schrire, B. D., Lewis, G. P. \& Lavin, M. (2005b). Biogeography of the Leguminosae. In: Lewis, G. P., Schrire, B. D., Mackinder, B. \& Lock, M. (eds) Legumes of the World, pp. 21-54. Kew: Royal Botanic Gardens.

Schrire, B. D., Lavin, M., Barker, N. P. \& Forest, F. (2009). Phylogeny of the tribe Indigofereae (Leguminosae-Papilionoideae): geographically structured more in succulent-rich and temperate settings than in grass-rich environments. Amer. J. Bot. 96: 816-852. 
Schütz Rodrigues, R. \& Azevedo Tozzi, A. M. G. (2007). Morphological analysis and re-examination of the taxonomic circumscription of Acosmium (Leguminosae, Papilionoideae, Sophoreae). Taxon 56: 439-452.

Seigler, D. S. \& Ebinger, J. E. (2005). New combinations in the genus Vachellia (Fabaceae: Mimosoideae) from the New World. Phytologia 87: 139-178.

Seigler, D. S., Ebinger, J. E. \& Miller, J. T. (2006). The genus Senegalia (Fabaceae: Mimosoideae) from the New World. Phytologia 88: 38-93.

Silva, L. A. \& Scariot, A. (2004). Comunidade arbórea de uma floresta estacional decídua sobre afloramento calcário na bacia do Rio Paraná. Árvore 28: 61-67.

Smith, A. C. \& Johnston, I. M. (1945). A phytogeographic sketch of Latin America. In: Ver door n, F. (ed.) Plants and Plant Science in Latin America, pp. 11-18. Waltham: Chronica Botanica Co.

Spichiger, R., Calenge, C. \& Bise, B. (2004). Geographical zonation in the Neotropics of tree species characteristic of the Paraguay-Paraná Basin. J. Biogeogr. 31: 1489-1501.

Spichiger, R., Bise, B., Calenge, C. \& Chatelain, C. (2006). Biogeography of the forests of the Paraguay-Paraná Basin. In: Pennington, R. T., Lewis, G. P. \& R atter, J. A. (eds) Neotropical Savannas and Seasonally Dry Forests: Plant Diversity, Biogeography, and Conservation, pp. 193-211. Boca Raton: CRC Press.

Takntajan, A. L. (1986). Floristic Regions of the World. Berkeley: University of California Press.

Ulibar ri, E. A. (1996). Sinopsis de Caesalpinia y Hoffmannseggia (LeguminosaeCaesalpinioideae) de Sudamérica. Darwiniana 34: 299-348.

Vanni, R. (1994). Novedad en Tephrosia (Leguminosae) para la flora argentina. Bol. Soc. Argent. Bot. 30: 117-118.

Velloso, A. L., Sampaio, E. V. S. B. \& Pareyn, F. G. C. (2002). Ecorregiões propostas para o bioma Caatinga. Recife: Associação Plantas do Nordeste, Instituto de Conservação Ambiental, The Nature Conservancy do Brasil.

Werneck, F. P., Costa, G. C., Colli, G. R., Prado, D. E. \& Sites Jr. J. W. (2011). Revisiting the historical distribution of Seasonally Dry Tropical Forests: new insights based on palaeodistribution modelling and palynological evidence. Global Ecol. Biogeogr. 20: 272-288.

Received 11 March 2014; accepted for publication 7 October 2014; first published online 3 December 2014 